\title{
Changes in hormonal balance as key to reserve degradation after dormancy overcoming in Annona macroprophyllata and Annona purpurea seeds
}

\author{
Gisela Ferreira ${ }^{1}$, Ivan De-la-Cruz-Chacón ${ }^{2}$, Alma Rosa González-Esquinca ${ }^{3}$
}

\begin{abstract}
Studies on the effect of the applying of phytoregulators to overcome seed dormancy have been carried out in Annonaceae species, thus the endogenous relationship between abscisic acid and gibberellins after the application of phytoregulators needs to be known in these species. Considering the importance of hormonal balance in dormancy mechanisms, the aim of this research was to elucidate how endogenous $\mathrm{ABA}$ and GA concentrations change after the application of phytoregulators in seeds and how these changes affect reserve degradation during germination of Annona macroprophyllata and A. purpurea seeds. Seeds were submitted to three conditions: - no soaking, soaking-in-water and soaking-in-GA ${ }_{4+7}+$ benzyladenine. ABA, GA, lipids, proteins, and total soluble sugars were quantified at $0,2,5,10$, and 15 days after the beginning of treatments. The application of phytoregulators led change of the hormonal balance inducing increase in endogenous GA and reduction in ABA levels since seed soaking. During imbibition, the degradation of seed reserves (breaks proteins first, and then soluble sugars and finally lipids) was observed and complete germination was obtained after 10 days, with primary root emission. In both species, dormancy can be broken soon after seed dispersal when the balance between GA and ABA is endogenously changed (by exogenous application of phytoregulators), leading to metabolic reserve degradation and germination.

Index terms: abscisic acid, gibberellins, germination, lipids, proteins, soluble sugars, plant growth regulators, phytoregulators.
\end{abstract}

Corresponding author: aesquinca@unicach.mx

Received: June 11,2020 Accepted: October 07, 2020

Copyright: All the contents of this journal, except where otherwise noted, is licensed under a Creative Commons Attribution License.

\section{(cc) $\mathrm{EY}$}

\section{Câmbios no balanço hormonal como chave para degradação de reservas após a superação da dormência de sementes de Annona macroprophyllata e Annona purpurea}

\begin{abstract}
Resumo - Estudos sobre o efeito da aplicação de reguladores vegetais para a superação da dormência de sementes têm sido realizados em espécies de Annonaceae, deste modo a relação endógena entre o ácido abscísico e as giberelinas, após a aplicação de reguladores vegetais, necessita ser mais bem estudada nesta família. Considerando a importância do balanço hormonal nos mecanismos de dormência, o objetivo deste trabalho foi elucidar como as concentrações endógenas de ABA e GA se modificam após a aplicação de reguladores vegetais em sementes durante a superação da dormência e como essas alterações afetam a degradação de reservas durante a germinação de sementes de Annona macroprophyllata e A. purpurea logo após tal superação. As sementes foram submetidas a três condições: - sem imersão; imersão em água, e imersão em $\mathrm{GA}_{4+7}+$ benzyladenina. ABA, GA, lipídios, proteínas e açúcares solúveis totais foram quantificados aos $0 ; 2 ; 5 ; 10$ e 15 dias após o início dos tratamentos. A aplicação dos reguladores levou à alteração do balanço hormonal, induzindo aumento do GA endógeno e redução dos níveis de ABA desde a embebição das sementes. Durante a embebição, foi observada a degradação de reservas das sementes (primeiro proteínas, depois os açúcares e finalmente os lipídios), e a germinação completa foi obtida após 10 dias do inicio dos tratamentos, com emissão da raiz primária. Em ambas as espécies, a dormência pode ser quebrada logo após a dispersão das sementes, quando o equilíbrio entre GA e ABA endógeno é alterado (pela aplicação exógena de reguladores vegetais), levando à degradação de reservas e à germinação.

Termos para indexação: ácido abscísico, giberelinas, germinação, lipídios, proteínas, açúcares solúveis, hormônios vegetais, reguladores vegetais.
\end{abstract}

\footnotetext{
${ }^{1} \mathrm{PhD}$, Associated Professor at Plant Biology: BBVPZ Department, Institute of Biosciences, São Paulo State University (Unesp), Botucatu-SP, Brazil. E-mail: gisela.ferreira@unesp.br(ORCID:0000-0002-3065-2152)

${ }^{2} \mathrm{PhD}$, Associated Professor at Instituto de Ciencias Biológicas, Universidad de Ciencias y Artes de Chiapas (UNICACH), Tuxtla Gutierrez, Chiapas, México. E-mail: ivan.cruz@unicach.mx (ORCID: 0000-0001-9908-6278)

${ }^{3} \mathrm{PhD}$, Researcher at Instituto de Ciencias Biológicas, Universidad de Ciencias y Artes de Chiapas (UNICACH), Tuxtla Gutierrez, Chiapas, México.E-mail:aesquinca@unicach.mx (ORCID: 0000-0002-1075-3466)
} 


\section{Introduction}

The Annonaceae family has approximately 135 genera and 2500 species, with evolutionary, ecological, and pharmaceutical importance, in addition to its application in the food industry (CHATROU et al., 2012). Annonaceae seeds have acquired different dormancy mechanisms during evolution - morphological (RIZZINI, 1973); physiological (SILVA et al., 2007) and/ or morphophysiological (BRAGA et al., 2010; COSTA et al., 2011). Such mechanisms still need to be studied in several species, including Annona macroprophyllata and A. purpurea. Seed dispersal occurs at the end of the rainy season, with dormancy during the entire drought period (approximately 6 months) to Annona macroprophyllata (GONZALEZ-ESQUINCA et al., 2015) and more than six months to $A$. purpurea (GOMÉZ-CASTAÑEDA et al., 2003).

Several studies have been conducted to determine the factors involved with seed dormancy, including studies on tegument impermeability and embryo immaturity (FERREIRA et al., 2019). Studies on impermeability have demonstrated that seeds of both species $(A$. macroprophyllata and $A$. purpurea) present low imbibition rate, but are not impermeable (FERREIRA et al., 2014). Gonzalez-Esquinca et al. (2015) found that the tissues of embryos are differentiated at the time of seed dispersal, indicating absense the morphological problem in seed to germination. In another work, Campbell and Popenoe (1968) report the use of GA3 to overcome the dormancy of Annona diversifolia seeds. Similarly with A. macroprophyllata and A. purpurea seeds, Ferreira et al. (2016) observed that at the time of dispersion, seeds only germine with the application of plant growth regulators and the use of giberellins asociated with cytokinin $\left(\mathrm{GA}_{4+7}\right.$ $+\mathrm{N}$-(phenylmethyl)-aminopurine (benzyladenine - BA)) was more effective than giberellin $\mathrm{GA}_{3}$ to break dormancy in both seed species.

The effect of gibberellins and cytokinins to overcome dormancy caused by abscisic acid (ABA) is well known (KOORNEEF et al., 2002; GUBLER et al., 2005; BEWLEY et al., 2013). Since dormancy is overcome, gibberellins promote the biosynthesis of hydrolytic enzymes that act in reserve degradation, releasing energy and substrate for germination (MIRANSARI; SMITH, 2014). Cytokinins act at the various germination stages, inducing reserve degradation by increasing amylolytic and proteolytic activity (BEWLEY et al., 2013), also acting on cell division during germination (HEYL et al., 2012).

Although studies on dormancy have been carried out for several Annonaceae species (SILVA et al., 2007; GONZÁLEZ-ESQUINCA et al., 2015), studies have demonstrated the effect of the application of plant growth regulators on seed germination (STENZEL, 2003; OLIVEIRA et al., 2010; SOKOLOWSKI; CICERO, 2011). The relationship between endogenous abscisic acid (ABA) and gibberellins (GA) after the application of plant growth regulators is well known in other botanical families (CHEN et al., 2010).

Studies on the germination and dormancy aspects of Annonaceae seeds are relatively scarce, especially when the study is about the metabolic processes that occur during germination. It is known that in other species, the balance between ABA and GA is responsible for controlling dormancy and germination, which has not been discussed for Annonaceae.

Considering the importance of hormonal balance in dormancy mechanisms, the present study aimed at elucidating how endogenous $\mathrm{ABA}$ and GA concentrations change after the application of plant growth regulators in seeds and how these changes affect reserve degradation during germination of Annona macroprophyllata and A. purpurea seeds.

\section{Materials and methods}

Experimental design, treatments and evaluations Annona macroprophyllata Donn.Sm. (三 Annona diversifolia Saff.) and Annona purpurea Moc. \& Sessé ex Dunal fruits were obtained at the municipality of San Lucas, Chiapas, Mexico, from 18 and 12 trees, respectively, from non-commercial orchards. About 90 and 60 fruits of each species were collected and obtained, on average, 50 and 70 seeds per fruit, respectively. Seeds were manually extracted, washed with distilled water and maintained in the shade at $25{ }^{\circ} \mathrm{C}\left( \pm 2{ }^{\circ} \mathrm{C}\right)$ during seven days for superficial drying. The water content of seeds ( $9 \%$ to A.macroprophyllata and $16 \%$ to A. purpurea) was determined using four replicates of 25 seeds (GOMES et al., 2019) by the method of drying at $105^{\circ} \mathrm{C}$ for 24 hours (BRASIL, 2009). To verify seed viability, the tetrazolium test was performed in four replicates of 25 seeds. Seeds were longitudinally cut and immersed in tetrazolium solution ( $1 \%$ concentration) in black germination boxes $(10 \times 10 \times 2 \mathrm{~cm})$ for 2 hours under constant temperature of $30{ }^{\circ} \mathrm{C} \pm 2{ }^{\circ} \mathrm{C}$ (GIMENEZ et al., 2014). Both species had embryos with $100 \%$ viability.

The experimental design was completely randomized, with three replicates per plot, in a $3 \times 5$ (treatments $\mathrm{x}$ evaluation times) factorial arrangement.

Treatments consisted of a) seeds without soaking, $b$ ) seeds soaked in distilled water for four days (called "seeds in water"), and c) seeds soaked in plant growth regulators (400 $\mathrm{mg} \mathrm{L}^{-1}$ of $\mathrm{GA}_{4+7}$ and $\mathrm{N}$-(phenylmethyl)-aminopurine (benzyladenine - BA), PROMALIN ${ }^{\circledR}$ a commercial product with the mixture of the two substances) solution for four days. The use of $\mathrm{GA}_{4+7}+\mathrm{BA}$ and its concentration (400 $\mathrm{mg} \mathrm{L}^{-1}$ ) were set based on previous experiments (FERREIRA et al., 2016). 
The phytoregulator solution was prepared by dissolving $22.2 \mathrm{~g}$ of the product per liter, Commercial mixture $\left(\right.$ PROMALIN $^{\circledR}$ ) contains $1.8 \%$ of each phytoregulator and the concentration of each substance was $400 \mathrm{mg} . \mathrm{L}^{-1}$. Soaking time (four days -96 hours) was set as a function of time required by phase I of the water acquisition curve (imbibition); soaking solutions were maintained under constant aeration through aquarium pumps (FERREIRA et al., 2014).

Seeds received treatments and then were placed in a roll of germination paper moistened with distilled water (2.5 times its dry weight). Then, seeds were maintained in germination chamber at $50-60 \%$ relative humidity, $30{ }^{\circ} \mathrm{C}\left( \pm 2{ }^{\circ} \mathrm{C}\right)$, and in the absence of light (FERREIRA et al., 2016) until collection at each germination stage (evaluation times) for biochemical analyses, when three replicates of each treatment were used for the performance of each biochemical analysis. The application of plant growth regulators in seeds promotes $71 \%$ germination on Annona macroprophyllata seeds and $29 \%$ on A. purpurea seeds. On the other hand, seeds without treatments do not germinate. These results were reported in Ferreira et al. 2016.

Evaluation times (zero, two, five, ten, and fifteen days after sowing) were determined as a function of germination stages according to previous experiment (FERREIRA et al., 2016). Time zero corresponded to the initial metabolic stage of seeds (before treatments). Times two and five days corresponded to intermediate stages, with no primary root protrusion. At ten and fifteen days, germinated seeds (that received $\mathrm{GA}_{4+7}+\mathrm{BA}$ ) presenting 1 $\mathrm{mm}$ and $1 \mathrm{~cm}$ primary root were collected, respectively. At the same times (ten and fifteen days) ungerminated seeds were collected (without primary root). Thus, seeds treated with $\mathrm{GA}_{4+7}+\mathrm{BA}$ and without treatments with no signal of germination were simultaneously collected.

Total soluble sugars, proteins, and lipids were quantified in endosperm samples of each treatment and at each evaluation time (without embryos). Furthermore, endosperms plus embryos were used for ABA and GA quantification.

\section{ABA and GA quantification}

The method for ABA and GA extraction and quantification was adapted by Kelen et al. (2004). Three replicates of five dry seeds $(\sim 5.5 \mathrm{~g})$ were soaked in $70 \%$ methanol and maintained at $4{ }^{\circ} \mathrm{C}$ for $12 \mathrm{~h}$. The material was submitted to vacuum filtration and rotaevaporation at $45{ }^{\circ} \mathrm{C}$ to remove methanol. The aqueous phase was adjusted to $\mathrm{pH} 8.5$ with $0.1 \mathrm{M}$ phosphate buffer and partitioned three times with ethyl acetate (AcOEt). The ethyl acetate phase was removed and the $\mathrm{pH}$ of the aqueous phase was adjusted to 2.5 with $1 \mathrm{~N} \mathrm{HCl}$. The material was again partitioned with EtOAc, the organic portion was filtered over anhydrous sodium sulfate, and AcOEt was evaporated.
ABA and GA were analyzed according to Kellen et al. (2004), and Bandurska et al. (2017), by High-Performance Liquid Chromatography (HPLC, PerkinElmer NCI 900 Series) in reverse phase (Spheri-5 RP-18, $100 \mathrm{~mm} \times 4.6$ $\mathrm{mm} ; 5 \mu \mathrm{m}$ particle diameter). The mobile phase consisted of acetonitrile: water (26:74). The isocratic flow rate was $1 \mathrm{~mL} \mathrm{m^{-1 }}$, and column temperature was maintained at $30{ }^{\circ} \mathrm{C}$. UV detection was performed at $210 \mathrm{~nm}$. The standard calibration curve of each plant growth regulator was made from stock solutions containing $250,225,150$, $100,50,25,12,6$; and $3 \mu \mathrm{MABA}$ and $275,250,200,150$, 100,50 , and $25 \mu \mathrm{M} \mathrm{GA}_{3}$. Linear regression curves were made for GA ( $\left.y=6403 x-182769, R^{2}=0.98\right)$ and ABA ( $y=$ $\left.20742 x+287104, R^{2}=0.99\right)$ contents. The Perkin Elmer Turbochrom software was used for data analysis and integration of chromatographic peaks.

Samples were dissolved in ethanol to obtain concentration of $2 \mathrm{mg} \mathrm{L}^{-1}$. Then, $20 \mu \mathrm{L}$ of such solutions were injected into the HPLC system for analysis. The identification of hormones was confirmed by comparing peaks obtained using HPLC and the UV spectrum of pure standards. GAs were expressed as their total content.

\section{Total soluble sugar quantification}

Total soluble sugars were extracted according to Garcia et al. (2006) and quantified through the phenolsulfuric acid method (DUBOIS et al., 1956). Extraction was performed using three replicates of dry seeds $(\sim 1.2 \mathrm{~g}$ per replicate) from each treatment. Samples were ground in $10 \mathrm{~mL}$ of $80 \%$ ethanol and then maintained in water bath at $90{ }^{\circ} \mathrm{C}$ for $5 \mathrm{~min}$ to inactivate enzymes. After, they were centrifuged at $1000 \mathrm{~g}$ at $4{ }^{\circ} \mathrm{C}$ for $5 \mathrm{~min}$ and the residue was extracted twice more with $80 \%$ ethanol at $80{ }^{\circ} \mathrm{C}$ for $5 \mathrm{~min}$ and once more with water at $60{ }^{\circ} \mathrm{C}$ for $5 \mathrm{~min}$. For each sample, extracts were combined and submitted to vacuum concentration at $35^{\circ} \mathrm{C}$.

\section{Protein quantification}

For protein extraction (SUDA; GIORGINI 2000), three replicates of dry seeds $(\sim 1.2 \mathrm{~g})$ from each treatment were considered. Proteins were extracted from endosperm consecutively according to their solubility - albumins (with distilled water), globulins (with 5\% sodium chloride), prolamins ( $60 \%$ ethanol), and glutelins (with $0.4 \%$ sodium hydroxide) every $24 \mathrm{~h}$. Extracts were centrifuged at $15,000 \mathrm{~g}$ for $30 \mathrm{~min}$ and supernatants were collected and used for protein quantification according to Bradford (1976). 


\section{Lipid quantification}

Lipids were extracted according to Ambalkar et al. (2011) from three replicates of three seeds $(\sim 4.0 \mathrm{~g}$ per replicate) from each treatment. Endosperms were ground in mortar and then lipids were extracted with hexane under continuous flow for three periods of $8 \mathrm{~h}$. During each extraction period, the supernatant was collected, filtered, concentrated and stored.

\section{Statistical analysis}

Data regarding ABA, GA, total soluble sugar, protein, and lipid contents are indicated in dry basis and were submitted to analysis of variance, with posterior construction of polynomial regression models corresponding to the period between beginning of soaking and visible germination (PIMENTEL-GOMES, 2009).
Correlation analysis among ABA, GA, sugars, proteins and lipid contents was performed. For analysis purposes, $\mathrm{r}$ values between $0.8-1.0$ were considered strong correlations. Statistical analysis was performed using the SAS and PAST software (SAS institution, Cary, NC; Hammer et al, 2001).

\section{Results and discussion}

In ungerminated seeds (without soaking and soaked in water), reductions in $\mathrm{ABA}$ content were not observed over time, while small changes were observed in GA content. Nevertheless, seeds soaked in $\mathrm{GA}_{4+7}+$ BA showed reduction in $\mathrm{ABA}$ content and increased GA levels from the beginning of soaking until the beginning of primary root protrusion $(1 \mathrm{~mm})$ after 10 days (Figure $1 \mathrm{~A}-\mathrm{D})$.

$(\bullet)$ seeds without soaking $(\square)$ soaking in water soaking $(\bullet)$ soaking in $\mathrm{GA}_{4+7}+\mathrm{BA}$

A. macroprophyllata
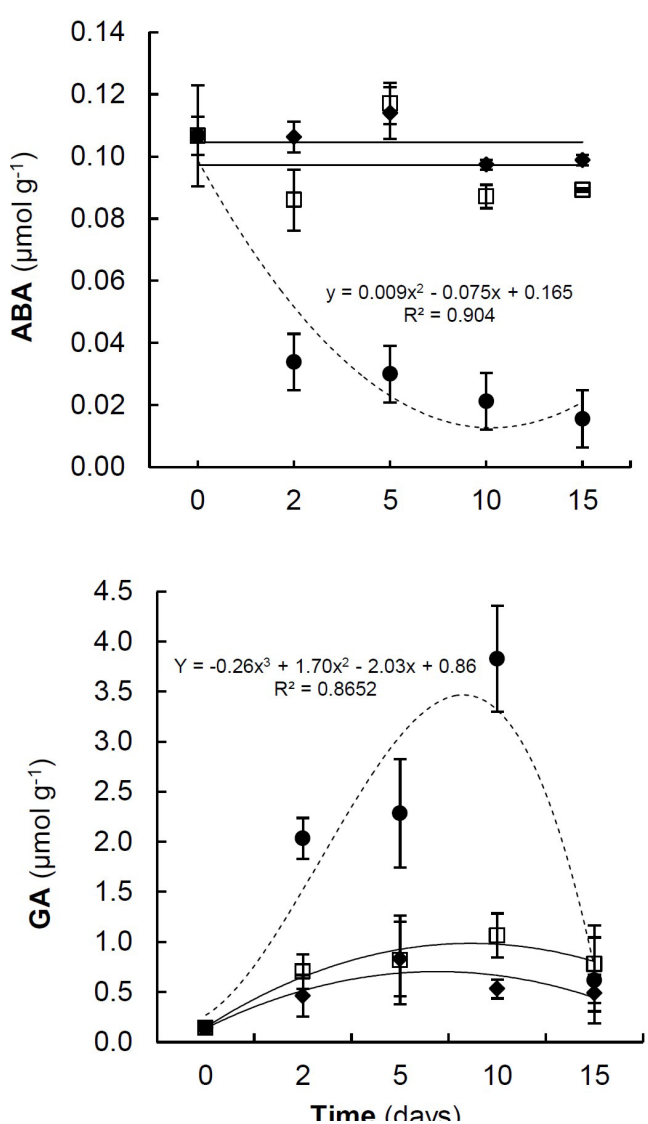

A. purpurea
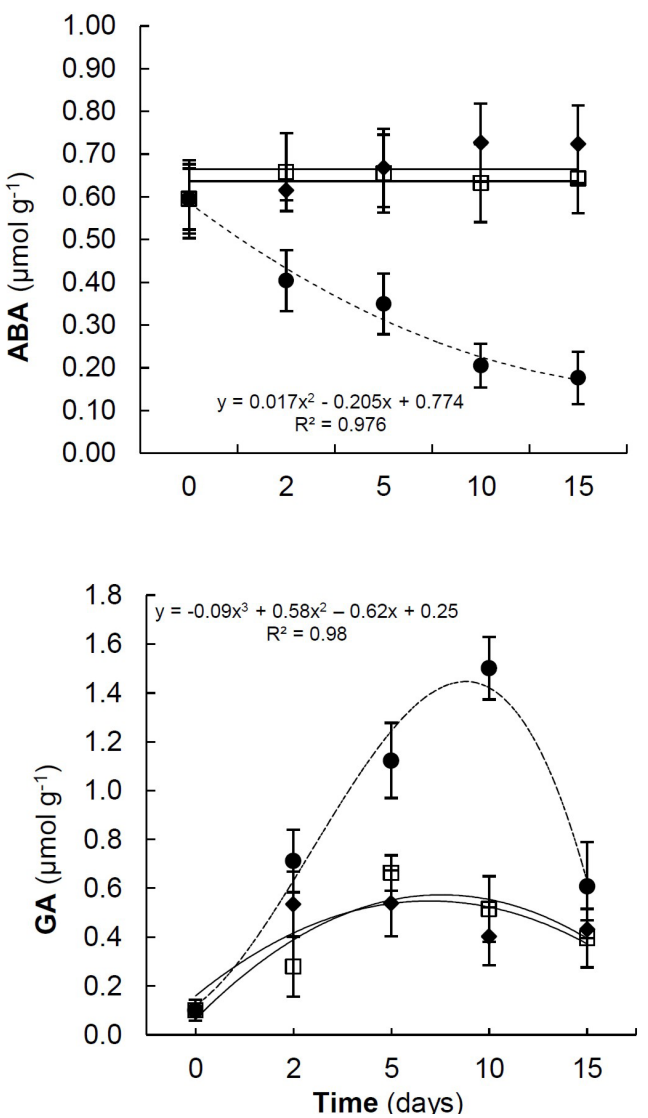

Figure 1 - Abscisic acid (ABA) and giberellin (GA) contents in Annona macroprophyllata (A and C) and A. purpurea $\left(\mathrm{B}\right.$ and D) seeds without soaking $(\bullet)$, soaked in water $(\square)$ and soaked in $\mathrm{GA}_{4+7}+\mathrm{BA}(\bullet)$ evaluated at $0,2,5,10$, and 15 days after treatments. Equations represent treatments with plant regulators. The values represent the average of replicates, and standard deviations are indicated.

It must be emphasized that Annona macroprophyllata seeds showed higher GA content compared to A. purpurea from seed dispersal and particularly after treatment with plant growth regulators. The application of $\mathrm{GA}_{4+7}+\mathrm{BA}$ led to increase in GA content over time, while ABA content decreased. After 2 days of soaking in plant growth regulators, reduction in $\mathrm{ABA}$ content was constant in both species, although A. purpurea seeds showed the highest ABA levels even after treatment with plant growth regulators (Fig. 1B). 
In both species, seeds treated with $\mathrm{GA}_{4+7}+\mathrm{BA}$ showed constant degradation of albumins (Fig. 2 A-B), differing from ungerminated seeds (without soaking and soaked in water). The degradation level was different in each species. Seeds without soaking in water, $A$. macroprophyllata seeds (time 0), showed $9668.3 \mu \mathrm{g} \mathrm{g}^{-1}$ albumin content, decreasing to $2347.3 \mu \mathrm{g} \mathrm{g}^{-1}$ at 15 days after the beginning of soaking in plant growth regulators. In A. purpurea, initial level was $19632.4 \mu \mathrm{g} \mathrm{g}^{-1}$ and reduced to $6368.5 \mu \mathrm{g} \mathrm{g}^{-1}$ at the end of the evaluation period.

$(\triangleleft)$ seeds without soaking $(\square)$ soaking in water soaking $(\bullet)$ soaking in $\mathrm{GA}_{4+7}+\mathrm{BA}$
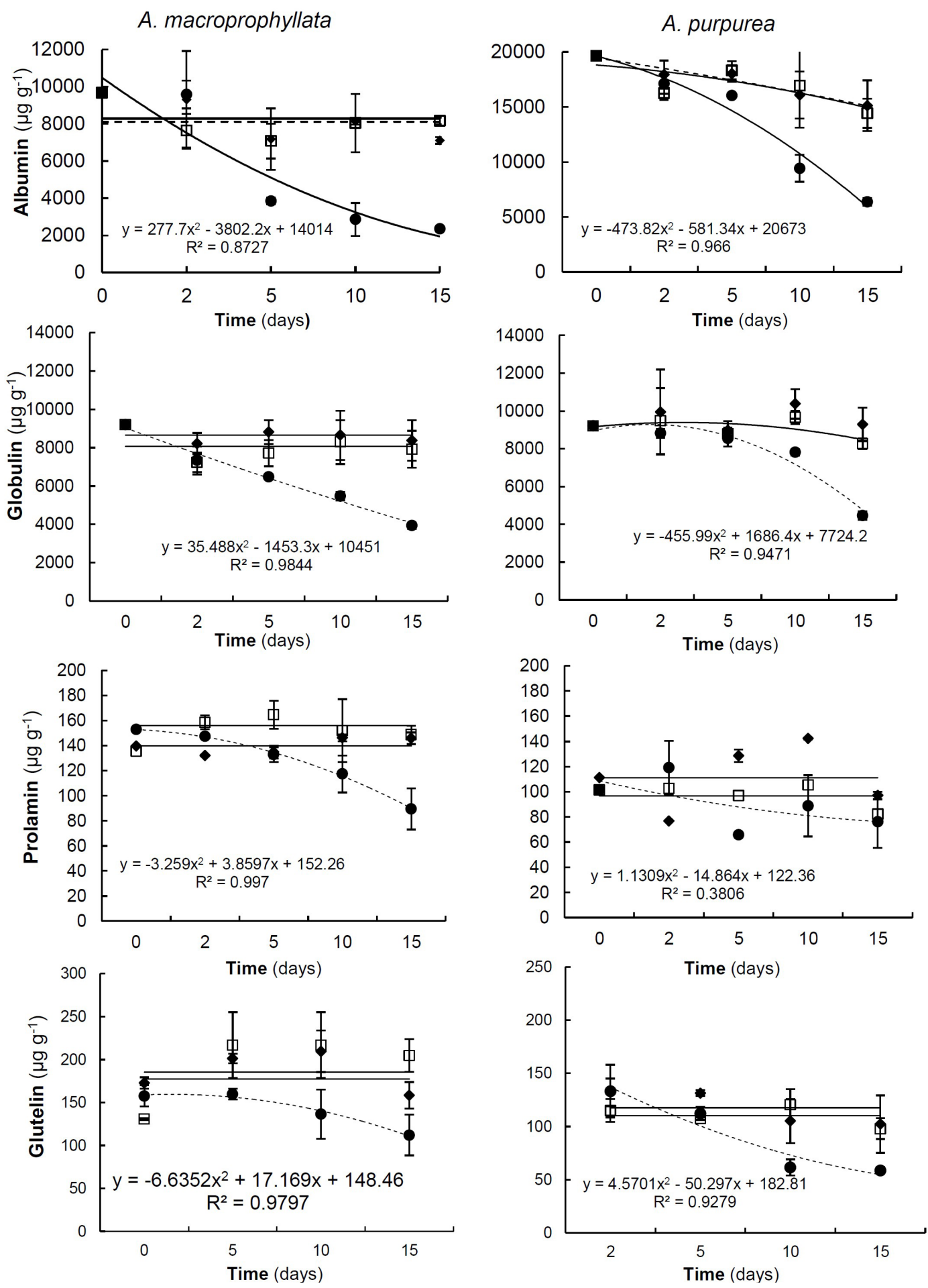

Figure 2. Albumin, globulin, prolamin and glutelin contents in Annona macroprophyllata (A. C, E and G) and A. purpurea (B, D , F and H) seeds without soaking $(\bullet)$, soaked in water $(\square)$ and soaked in $\mathrm{GA}_{4+7}+\mathrm{BA}(\bullet)$ evaluated at $0,2,5,10$, and 15 days after soaking. Equations represent treatments with plant regulators. The values represent the average of replicates, and standard deviations are indicated. 
Distinct patterns between species were observed regarding albumin and globulin degradation in seeds treated with $\mathrm{GA}_{4+7}+$ BA. In A. macroprophyllata, slow albumin degradation was detected at the beginning of evaluations ( 0 and 2 days), while sharp globulin degradation occurred from the beginning of soaking (Fig. 2C). In A. purpurea seeds, albumin and globulin (Fig. 2 B-D) degradation started later (10 days), but it was similar to that observed in A. macroprophyllata (4461 and 3929 ug $\mathrm{g}^{-1}$, respectively).

Prolamins and glutelins were also degraded in both species over time due to the application of $\mathrm{GA}_{4+7}+$ BA. Nevertheless, such proteins showed 100-fold lower contents and their degradation was only significant at 15 days (Fig. 2 E-H).
Regarding total soluble sugar degradation, dormant A. macroprophyllata and A. purpurea seeds showed small decrease in sugar content regardless of soaking in water, thus requiring exogenous application of $\mathrm{GA}_{4+7}+\mathrm{BA}$ to stimulate higher degradation (Fig. 3 A-B). Total soluble sugar degradation is higher as more energy is required for embryo development, thus resulting in lower total soluble sugar content, which was observed at $1 \mathrm{~cm}$ primary root. Comparing species when treated with $\mathrm{GA}_{4+7}+\mathrm{BA}, A$. purpurea seeds showed lower initial sugar content and faster degradation since the beginning of soaking (Fig. 3B). However, both species showed similar sugar levels in primary root protrusion.

$(\bullet)$ seeds without soaking $(\square)$ soaking in water soaking $(\bullet)$ soaking in $\mathrm{GA}_{4+7}+\mathrm{BA}$
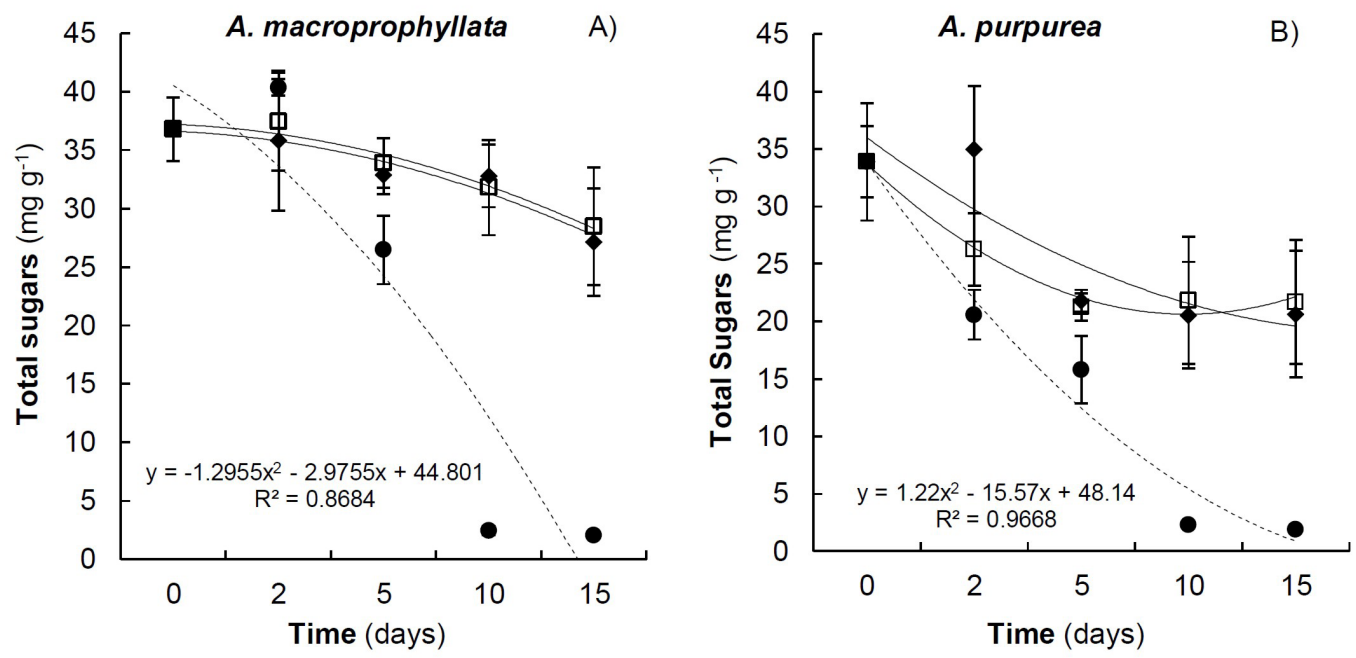

Figure 3 - Total soluble sugar content in A) Annona macroprophyllata and B) A. purpurea seeds without soaking ( $\bullet$ ), soaked in water $(\square)$ and soaked in $\mathrm{GA}_{4+7}+\mathrm{BA}(\bullet)$ evaluated at $0,2,5,10$, and 15 days after the treatments. Equations represent treatments with plant regulators. The values represent the average of replicates, and standard deviations are indicated.

Lipid reserves were degraded in seeds from all treatments and with the application of $\mathrm{GA}_{4+7}+\mathrm{BA}$ (Fig. 4), degradation was faster compared to the others treatments. In A. macroprphyllata seeds (Fig. 4A), such reduction was more evident at 15 days, while $A$. purpurea seeds showed greater energy consumption after 10 days for the maintenance of seedling development (Fig. 4B).

Thus, application of $\mathrm{GA}_{4+7}+\mathrm{BA}$ led to faster reserve degradation, mainly of proteins and total sugars, followed by lipids, which confirms the action of such plant growth regulators on reserve degradation.
Correlation analysis between presence of plant regulators and reserve amounts (Tabela 1) indicates that, in general, the higher the presence of $\mathrm{ABA}(\mathrm{r}=0.72-0.99)$, the higher the content of reserve macromolecules. These relationships were more evident in a larger number of reserve molecule types in Annona purpurea than in $A$. macroprophyllata. 
$(\bullet)$ seeds without soaking $(\square)$ soaking in water soaking $(\bullet)$ soaking in $\mathrm{GA}_{4+7}+\mathrm{BA}$

A. macroprophyllata

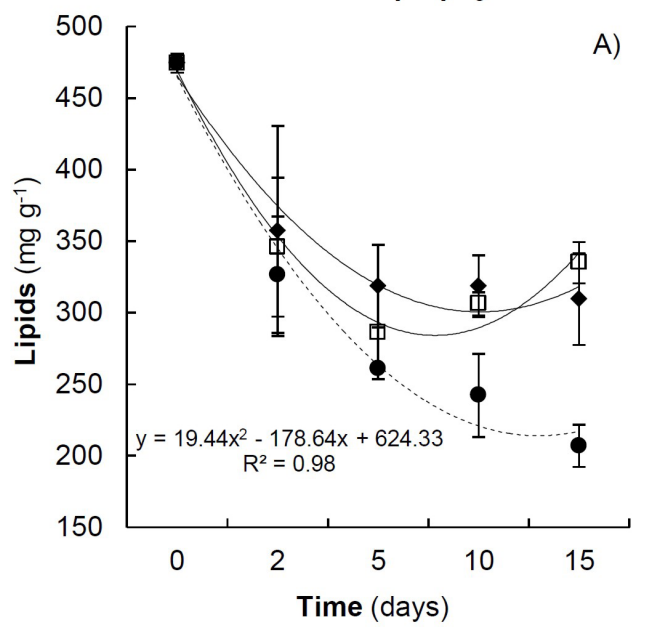

A. purpurea

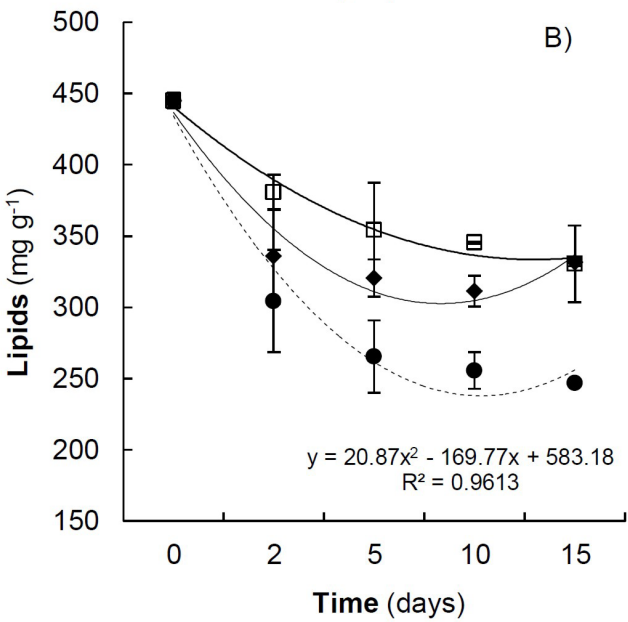

Figure 4 - Lipid content in A) Annona macroprophyllata and B) A. purpurea seeds without soaking ( $\downarrow$ ), soaked in water $(\square)$ and soaked in $\mathrm{GA}_{4+7}+\mathrm{BA}(\bullet)$ evaluated at $0,2,5,10$, and 15 days after the treatments. Equations represent treatments with plant regulators. The values represent the average of replicates, and standard deviations are indicated.

Table 1. Correlation analysis between presence of phytoregulators and reserves of Annona macroprophyllata and Annona purpurea.

\begin{tabular}{|c|c|c|c|c|}
\hline & \multicolumn{2}{|c|}{ Annona macroprophyllata } & \multicolumn{2}{|c|}{ Annona purpurea } \\
\hline & $\mathbf{A B A}$ & GA & ABA & GA \\
\hline albumin & $0.7260(0.1649)$ & $-0.3905(0.5158)$ & $\mathbf{0 . 9 3 6 9}(0.0189)$ & $-0.4491(0.4481)$ \\
\hline globulin & $\mathbf{0 . 8 7 5 2}(0.0419)$ & $-0.2881(0.6383)$ & $0.7537(0.1412)$ & $-0.0479(0.9391)$ \\
\hline prolamin & $0.6931(0.1944)$ & $-0.0689(0.9122)$ & $0.4910(0.4009)$ & $-0.3728(0.5366)$ \\
\hline glutelin & $0.5175(0.3719)$ & $0.08959(0.8861)$ & $0.9017(0.0365)$ & $-0.5246(0.3641)$ \\
\hline total soluble sugars & $0.6159(0.2686)$ & $-0.3163(0.6041)$ & $\mathbf{0 . 9 9 6 9}(0.0002)$ & $-0.6972(0.1907)$ \\
\hline lipids & $0.9683(0.0067)$ & $-0.4995(0.3915)$ & $0.9296(0.0222)$ & $-0.7686(0.1287)$ \\
\hline
\end{tabular}

Correlation analysis (Pearson r). Values close to +1 indicate close direct relationships and close to -1 indicate strong inverse associations.

On the other hand, inverse linear relationships between gibberellins and reserves are statistically weak, which indicates the activity of these plant regulators to trigger mobilization, that is, there is an exact balance point between ABA decrease and increase of gibberellins, leading to germination and reserve degradation.

In the present study, ABA content was higher than GA in freshly dispersed A. macrophyllata and A. purpurea seeds, thus explaining the absence of germination. ABA accumulation in dormant seeds occurs in the final maturation stages, inducing dormancy (GUBLER et al., 2005; BENTSIN and KOORNNEEF, 2008) and ensuring the survival of species under adverse conditions. Such a strategy would allow both species to withstand dry and hot months until the beginning of the rainy season, as also suggested by González-Esquinca et al. (2015).

Thus, there is probable temporary inability of seeds of both species to increase endogenous GA due to ABA content with the objective of guaranteeing dormancy
(YAMAGUCHI, 2008; BEWLEY et al., 2013; KANG et al., 2015). Such fact was demonstrated when GA content did not increase after reactivation of seed metabolism during soaking in water. The hormonal balance needs to be changed for dormancy overcoming, either in response to environmental changes or by exogenous application of germination promoters, which was performed and observed with the application of $\mathrm{GA}_{4+7}+\mathrm{B}$ in the present study.

In the present study, $\mathrm{GA}_{3}$ was effectively used as a reference to express the content of total gibberellins. $\mathrm{GA}_{3}$ is a phytoregulator involved in seed germination (CHEN et al., 2010), especially in Annona diversifolia (CAMPBELL; POPENOE, 1968). Although there are more active forms of gibberellins (OGAWA et al., 2003), the increase in $\mathrm{GA}_{3}$ indicates (even when not directly related to biosynthesis) an increase in total gibberellins. It has recently been proposed that $\mathrm{GA}_{3}$ can be converted into GA1 (CHEN et al., 2008), which in fungi is a more 
recurrent fact (SALAZAR CEREZO et al., 2018). For this reason, the presence of total gibberellins and not only $\mathrm{GA}_{3}$ has been reported. In addition, reduction in ABA content is not sufficient for dormancy overcoming, since changes in sensitivity to ABA and increased levels of promoters are needed, because seeds unable to produce GAs do not germinate (YAMAGUCHI, 2008; NONOGAKY et al., 2010; KANG et al., 2015). An increase in GA content leads to the synthesis of degradative enzymes for embryo development (KUCERA et al., 2005), and lipids and carbohydrates are used as energy source (PRITCHARD et al., 2002; SUBEDI; BHATTARAI 2003), while proteins and amino acids are used in the formation of new tissues (RAMAKRISHNA, 2007). In both species, reserve degradation began during imbibition phase in seeds treated with $\mathrm{GA}_{4+7}+\mathrm{BA}$. Among reserves, lipids were found in higher contents, followed by proteins and soluble sugars. Galastri (2008) detected higher protein and lipid contents in seeds of other Annonaceae species (Duguetia furfuracea and Xylopia emarginata) and detected higher starch content in Annona dioica seeds. Reduction in total sugar content was detected from the beginning of soaking in plant growth regulators in both species, until the protusion of the primary roots (end of germination). Similary, Gimenez et al. (2014) observed fast reduction from total soluble sugars in Annona emarginata seeds during imbibition (Phase I of the germination process), changed from $43 \mathrm{mg}$ $\mathrm{g}^{-1}$ in the beginning (seeds with $20 \%$ of water) to $29 \mathrm{mg}$ $\mathrm{g}^{-1}$ at the end of this phase, when seeds showed $35 \%$ of water. This rapid reduction in soluble sugar content may be related to its easy degradation for respiration activation and ATP generation for the biosynthesis of proteins and other molecules required for cell division and elongation or other physiological processes such as ATPase-mediated solute transport (BEWLEY et al., 2013). Soluble sugars represent less than $10 \%$ of the total lipid reserves of $A$. macroprophyllata and A. purpurea seeds. So, while these seeds have about $470 \mathrm{mg} \mathrm{g}^{-1}$ and $450 \mathrm{mg} \mathrm{g}^{-1}$ of lipids, they have $37 \mathrm{mg} \mathrm{g}^{-1}$ and $33 \mathrm{mg} \mathrm{g}^{-1}$ of sugars, respectively. The use of $\mathrm{GA}_{4+7}+\mathrm{BA}$ lead a rapid lipid degradation maybe to guarantee energy to the germination process.

With respect to proteins, although degradation has been considered a growth-related process in seedlings (Ramakrishna \& Rao 2005a, b), A. macroprophyllata and A. purpurea seeds showed degradation from the first two days of soaking in treatment with $\mathrm{GA}_{4+7}+\mathrm{BA}$. This faster protein degradation due to the aplication of plant growth regulators indicate a possible production of materials like amino acids, to produce new tisses, speeding up germination process, unlike other treatments. Moreover, albumin and globulin fractions were degraded in different ways, globulins were continuously degraded from the beginning of soaking, while albumins reached their maximum degradation at later germination stages, as also observed by Ramakrishna (2007) during the germination of Dolichos lablab vr. lignosus seeds. Schlereth et al. (2000) observed degradation of the majority of globulins from the embryonic axis of Vicia sativa seeds, showing radicle protrusion after $24 \mathrm{~h}$ of soaking, while degradation from cotyledons had not yet been detected. Early glutelin degradation during soaking was also observed by Suda and Giorgini (2000) in Euphorbia heterophylla seeds. The authors also found low prolamin contents in seeds of different Annonaceae species.

The two species evaluated in the present study were different regarding ABA content needed for maintaining dormancy and inducing germination. A. macroprophyllata required $0.10 \mu \mathrm{g} \mathrm{g}^{-1} \mathrm{ABA}$, while $A$. purpurea required $0.60 \mu \mathrm{g} \mathrm{g}^{-1}$ for maintaining dormancy. After application of plant growth regulators, reduction in ABA content was detected, reaching $0.02 \mu \mathrm{g} \mathrm{g}^{-1}$ (A. macroprophyllata) and $0.20 \mu \mathrm{g} \mathrm{g}^{-1}$ (A. purpurea) in germinated seeds, showing $1 \mathrm{~mm}$ primary root. Higher ABA content in A. purpurea seeds may be responsible for improved resistance for overcoming seed dormancy ( $29 \%$ germination). In this context, lower initial ABA content may have facilitated dormancy overcoming in A. macroprophyllata seeds ( $71 \%$ germination). It is noteworthy that in A. purpurea seeds with broken dormancy, ABA content was higher than in A. macroprophyllata seeds. However, in both species, the final GA content in germinated seeds was very similar.

While non-dormant seeds showed high metabolism and subsequent germination, dormant seeds showed metabolism with no sufficient changes for inducing germination. Such low metabolic activity is due to the need for dormancy overcoming for later germination, which is due to the high ABA content inhibiting the synthesis of GA and enzymes involved in reserve degradation (PEREZ-FLORES et al., 2003; ALI-RACHED et al., 2004; GUBLER et al., 2005). Thus, dormant seeds can support low level of metabolic activity during imbibition (Phase I) and Phase II, but they did not reach Phase III with visible germination (BEWLEY et al., 2013).

\section{Conclusion}

This study allows conclude that Annona macroprophyllata and A. purpurea seeds are dispersed with ABA content preventing GA synthesis, thus demonstrating their inability to produce GAs after dispersal, ensuring dormancy during the dry period. Dormancy overcoming occurs by changing the relationship between endogenous $\mathrm{ABA}$ and GA - in the present study by the application of GA - leading to reduction in ABA content, which results in increased GA synthesis and reserve degradation, thus resulting in complete germination with primary root protrusion. 


\section{Acknowledgments}

This study was financed in part by the Coordenação de Aperfeiçoamento de Pessoal de Nivel Superior Brasil (CAPES) - Finance Code 001", with posdoctorade scholarship to first autor.

\section{References}

ALI-RACHEDI, S.; BOUINOT, D; WAGNER, M.; BONNET, M.; SOTTA, B.; GRAPPIN, P.; JULLIEN, $M$. Changes in endogenous abscisic acid levels during dormancy release and maintence of mature seeds: studies with the Cape Verde Islands ecotype, the dormant model of Arabidopsis thaliana. Planta, Berlin, v.219, p.479488, 2004.

AMBALKAR, V.U.; SAPKAL, V.S.; TALIB, M.; KHANDELWAL, S.A. Soxhlet extraction of Neem seed (Azadirachta indica A. Juss) using hexane as a solvent. International Journal Chemical and Analytical Science, Amsterdam, v. 2, p.10-11, 2011.

BANDURSKA, H.; NIEDZIELA, J PIETROWSKABOREK, M.; NUC, K.; CHADZINIKOLAU T.; RADZIKOWSKA, D.. Regulation of proline biosynthesis and resistance to drought stress in two barley (Hordeum vulgare L.) genotypes of different origin. Plant Physiology and Biochemistry, Amsterdam, v.118, p.427-437, 2017.

BENTSINK L, KOORNNEEF M. Seed dormancy and germination. The Arabidopsis Book, Rockville, v.6, p.1-18, 2008.

BEWLEY, J.D.; BRADFORD, K.J.; HILHORST, H.W.M.; NONOGAKI, H. Seeds: physiology of development, germination and dormancy. $3^{\text {rd }}$ ed. London: Springer, 2013. 392p.

BRADFORD, M.M. A rapid and sensitive method for the quantification of microgram quantities of protein utilizing the principle of protein-dye binding. Analytical Biochemistry, Harlow, v.72, p.248-254. 1976.

BRAGA, J.F.; FERREIRA, G.; PINHO, S.Z.; BRAGA, L.F.; SOUSA, M.P. Germination of atemoya (Annona cherimola Mill. x A. squamosa L.) CV. Gefner seeds subjected to treatments with plant growth regulators. International Journal of Science and Nature, Daca, v.1, n.2, p.120-126, 2010.
BRASIL. Ministério da Agricultura. Regras para análise de sementes. Brasilia (DF): Departamento de Produção Vegetal, 2009. 398 p.

CAMPBELL, C.W. ; POPENOE, J. Effect of gibberellic acid on seed dormancy of Annona diversifolia Saff. Tropical Region American Society for Horticultural Science, Mount Vermon, v.11, p.33-36, 1968.

CHATROU, L.W.; PIRIE, M.D.; ERKENS, R.H.J.; COUVREUR, T.L.P.; NEUBIG, K.M.; ABBOTT, J.R.; MOLS, J.B.; MAAS, J.W.; SAUNDERS, R.M.K.; CHASE, M.W. A new subfamilial and tribal classification of the pantropical flowering plant family Annonaceae informed by molecular phylogenetics. Botanical Journal of the Linnean Society, Londres, v.169, p.5-40, 2012.

CHEN, S.Y.; CHIEN, C.T.; BASKIN, J.M.; BASKIN, C.C. Storage behavior and changes in concentrations of abscisic acid and gibberellins during dormancy break and germination in seeds of Phellodendron amurense var. wilsonii (Rutaceae). Tree Physiology, Oxford, v.30, n.2, p.275-284, 2010.

CHEN, S.Y.; KUO, S.R.; CHIEN, C.T. Roles of gibberellins and abscisic acid in dormancy and germination of red bayberry (Myrica rubra) seeds. Tree Physiology, Oxford, v.28, n.9, p.1431-1439, 2008.

COSTA, P.N.; BUENO, S.S.C.; FERREIRA, G. Fases da germinação de sementes de Annona emarginata (Schltdl.) $\mathrm{H}$. Rainer em diferentes temperaturas. Revista Brasileria de Fruticultura, Jaboticabal, v.33, n.1, p.253-260, 2011.

DUBOIS, M.; GILLES, K.A.; HAMILTON, J.K.; REBERS, P.A.T.; SMITH, F. Colorimetric method for determination of sugars and related substances. Analytical Biochemistry, Harlow, v.28, p.350-356, 1956.

FERREIRA, G.; GONZÁLEZ-ESQUINCA, A.R.; DE-LA-CRUZ-CHACÓN, I. Water uptake by Annona diversifolia Saff. and A. purpurea Moc. \& Sessé ex Dunal seeds (Annonaceae). Revista Brasileria de Fruticultura, Jaboticabal, v.36, n.1, p.288-295, 2014. Número Especial.

FERREIRA，G.; DE-LA-CRUZ-CHACON, I.; GONZALEZ-ESQUINCA, A. R. Overcoming seed dormancy in Annona macroprophyllata and Annona purpurea using plant growth regulators. Revista Brasileira de Fruticultura, Jaboticabal, v. 38, n. 3, e-234, 2016. 
FERREIRA, G.; DE-LA-CRUZ-CHACÓN, I.; BOARO, C.S.F.; BARON, D.; LEMOS, E.E.P.D. Propagation of Annonaceous plants. Revista Brasileira de Fruticultura, Jaboticabal, v. 41, n.1, e-500, 2019.

GALASTRI, N.A. Morfoanatomia e ontogênese de frutos e sementes de Annona dioica A.St.-Hil., Duguetia furfuracea (A.St.-Hil.) Saff. e Xylopia emarginata Mart. (Annonaceae). 2008. Dissertação (Mestrado) - Instituto de Biociências, Universidade Estadual Paulista, Botucatu, 2008.

GARCIA, I.S.; SOUZA, A.; BARBEDO, C.J.; DIETRICH, S.M.C.; FIGUEIREDO-RIBEIRO, R.C.L. Changes in soluble carbohydrates during storage of Caesalpinia echinata LAM. (Brazilwood) seeds, an endangered leguminous tree from the Brazilian Atlantic Forest. Brazilian Journal of Biology, São Carlos, v. 66, p.739-745, 2006.

GIMENEZ, J.I.; FERREIRA, G.; CAVARIANI, C. Tetrazolium test for assessment of seed viability of atemoia (Annona cherimola Mill. x A. squamosa L.). Journal of Seed Science, Londrina, v.36, n.3, p.357-361, 2014.

GOMES, R.L.; PASSOS, J.R.S.; GIMENEZ, J.I.; SOUSA, M.C.;DE-PIERI-OLIVEIRA, M.F., MIMI, C.O.; FERREIRA, G. Optimum Sample Size in the gerrmination of Atemoya seeds (Annona $\times$ atemoya Mabb.). Journal of Agricultural Science, Cambridge, v.11, n.7, p.239$245,2019$.

GOMÉZ-CASTAÑEDA，J.A.; RAMIREZ，H; BENAVIDES-MENDOZA, A.; ENCINA-RODRIGUEZ, L.I. Germinación y crecimiento de plántula en chincuya (Annona purpurea Moc y Sessé) y su relación con los niveles de giberelinas y ácido abscísico. Revista Chapingo, Chapingo, v.9, n.2, p. 243-253, 2003.

GONZÁLEZ-ESQUINCA, A.R.; DE-LA-CRUZCHACÓN, I.; DOMÍNGUEZ-GUTÚ, L.M. Dormancy and germination of Annona macroprophyllata (Annonaceae): the importance of the micropylar plug and seed position in the fruits. Botanical Sciences, Ciudad de México, v. 93, n.3, p.1-7, 2015.

GUBLER, F.; MILLAR, A.A.; JACOBSEN, J.V. Dormancy release, ABA and pre-harvest sprouting. Current Opinion in Plant Biology, Saint Louis, v. 8, p.183-187, 2005.
HAMMER, Ø.; HARPER, D.A.T.; RYAN, P.D. PAST: Paleontological statistics software package for education and data analysis. Palaeontologia Electronica, College Station, v.4, n.1, p.1-9, 2001.

HEYL, A.; RIEFLER, M.; ROMANOV, G.A.; SCHMÜLLING, T. Properties, functions and evolution of cytokinin receptors. European Journal of Cell Biology, Zurich, v.9, n.4, p. 246-256.

KANG, J.; YIM, S.; CHOI, H.; KIM, A.; LEE, K.P.; LOPEZ-MOLINA, L. MARTINOIA, E.; LEE, Y.Abscisic Acid transporters cooperate to control seed germination. Nature Communications, Londres, v.6, p.1-10, 2015.

KELEN, M.; DEMIRALAY, E.Ç.; SEN, S.;ALSANCAK, G.Ö. Separation of abscisic acid, indole-3-acetic acid, gibberellic acid in $99 \mathrm{R}$ (Vitis berlandierix Vitis rupestris) and rose oil (Rosa damascene Mill.) by reversed phase liquid chromatography. Turkish Journal of Chemistry, Ankara, v. 28, p.603-610, 2004.

KOORNNEEF, M.; BENTSINK, L.; HILHORST, H. Seed dormancy and germination. Current Opinion Plant Biology, London, v. 5, p. 33-36, 2002.

KUCERA, B.; COHN, M.A.; LEUBNER-METZGER, G. Plant hormone interactions during seed dormancy release and germination. Seed Science Research, Wallingford, v.15, p.281-307, 2005.

MIRANSARI, M.; SMITH, D.L. Plant hormones and seed germination. Environmental and Experimental Botany, Oxford, v.99, p.110-121, 2014.

NONOGAKI, H.; BASSEL, G.W.; BEWLEY, J.D. Germination-still a mystery. Plant Science, Limerick, v.179, p.574-581, 2010.

OGAWA, M.; HANADA, A.; YAMAUCHI, Y.; KUWAHARA, A.; KAMIYA, Y.; YAMAGUCHI, S. Gibberellin biosynthesis and metabolism: A convergent route for plants, fungi and bacteria. Plant Cell, Rockville, v.15, p.1591-1604, 2003.

OLIVEIRA, M.C.; FERREIRA, G.; GUIMARÃES, V.F.; DIAS, G.B. Germinação de sementes de atemoia (Annona cherimola Mill. x A. squamosa L.) cv 'Gefner'submetidas a tratamentos com ácido Giberélico $\left(\mathrm{GA}_{3}\right)$ e ethephon. Revista Brasileria de Fruticultura, Jaboticabal, v.32, n.2, p.544-554, 2010. 
PÉREZ FLORES, L.; CARRARI, F.; OSUNA FERNÁNDEZ, R.; RODRÍGUEZ, M.V.; ENCISO, S.; STANELLONI,R.; SÁNCHEZ, R.A.; BOTTINI, R.; IUSEM, N.D.; BENECH-ARNOLD, R.L. Expression analysis of a GA 20 oxidase in embryos from two sorghum lines with contrasting dormancy: possible participation of this gene in the hormonal control of germination. Journal of Experimental Botany, Oxford, v.54, p.2071-2079, 2003.

PIMENTEL-GOMES, F. Curso de estatística experimental. 15. ed. Piracicaba: ESALQ, 2009. 75p.

PRITCHARD, S.L.; CHARLTON, W.L.; BAKER, A.; GRAHAM, I.A. Germination and storage reserve mobilization are regulated independently in Arabidopsis. The Plant Journal, Oxford, v. 31, n.5, p.639-647, 2002.

RAMAKRISHNA, V. Mobilization of albumins and globulins during germination of Indian bean (Dolichos lablab L. var. lignosus) seeds. Acta Botanica Croatica, Zagreb, v. 66, p. 135-142, 2007.

RAMAKRISHNA, V.; RAO, P.R. Axial control of protein reserve mobilization during germination of Indian bean (Dolichos lablab L.) seeds. Acta Biologica Szegediensis, Szeged, v.49, p.23-27, 2005a.

RAMAKRISHNA, V.; RAO, P.R. Purification of acidic protease from the cotyledons of germinating Indian bean (Dolichos lablab L. var. lignosus) seeds. African Journal of Biotechnology, Nairobi, v.4, p.703-707, 2005 b.

RIZZINI, C.T. Dormancy in seeds of Annona crassiflora Mart. Journal of Experimental Botany, Oxford, v. 24, p.17-123, 1973.

SALAZAR-CEREZO, S.; MARTINEZ-MONTIEL, N.; GARCIA-SANCHEZ, J.; PEREZ-Y-TERRON, R.;MARTÍNEZ-CONTRERAS, R. D. Gibberellin biosynthesis and metabolism: A convergent route for plants, fungi and bacteria. Microbiological Research, Jena, v.208, p.85-98, 2018.
SCHLERETH, A.; BECKER, C.; HORSTMANN, C.; TIEDEMANN, J.; MUNTZ, K. Comparison of globulin mobilization and cysteine proteinases in embryonic axes and cotyledons during germination and seedling growth of vetch (Vicia sativa L.). Journal Experimental Botany, Oxford, v.51, p.423-1433, 2000.

SILVA, E.A.A. da; MELO, D.L.B.; DAVIDE, A.C.; BODE, N.; ABREU, G.B.; FARIA, J.M.R.; HILHORST, H.W.M. Germination ecophysiology of Annona crassiflora seeds. Annals of Botany, Oxford, v. 99, n.5, p.823-830, 2007.

SOCOLOWSKI, F.; CICERO, S.M. Use of growth regulators to overcome seed dormancy in Xylopia aromatica (Annonaceae). Seed Science and Technology, Zurich, v.39, p.21-28, 2011.

STENZEL, N.M.C.; MURATA, I.M.; NEVES, C.S.V.J. Superação da dormência em sementes de atemóia e fruta-do-conde. Revista Brasileira de Fruticultura, Jaboticabal, v.25, n.2, p.305-308, 2003.

SUBEDI CK, BHATTARAI T. Effect of gibberellic acid on reserve food mobilization of maize (Zea mays L. var. Arun-2) endosperm during germination. Himalayan Journal of Sciences, Haridwar, v.1, p.99-102, 2003.

SUDA, C.N.K.; GIORGINI, J.F. Seed composition and mobilization during germination and initial seedling development of Euphorbia heterophylla. Revista Brasileira de Fisiología Vegetal, Londrina, v.12, p.226245, 2000.

YAMAGUCHI, S. Gibberellin metabolism and its regulation. Annual Review of Plant Biology, Palo Alto, v.59, p.225-251, 2008. 